\title{
PENGARUH EKSTRAK BUNGA FLAMBOYAN (Delonix regia Hook Raf) TERHADAP PERKECAMBAHAN DAN PERTUMBUHAN CABAI MERAH BESAR (Capsicum annuum L.)
}

\author{
EFFECT OF FLAMBOYANT FLOWER EXTRACT (Delonix regia Hook Raf) ON GERMINATION AND GROWTH RED \\ CHILLI LARGE (Capsicum annuum L.)
}

\author{
Royana Pakpahan, Ni Putu Adriani Astiti, I.G.A. Sugi Wahyuni \\ Jurusan Biologi, Fakultas Matematika dan Ilmu Pengetahuan Alam, \\ Universitas Udayana, Kampus Bukit Jimbaran
}

\section{INTISARI}

Penelitian ini bertujuan untuk mengetahui pengaruh ekstrak bunga flamboyant (Delonix regia Hook Raf) terhadap pertumbuhan tanaman cabai merah besar (Capsicum annuum L.), sebagai pemanfaatan lahan dibawah naungan pohon flamboyan. Rancangan percobaan yang digunakan Rancangan Acak Kelompok (RAK) dengan lima perlakuan konsentrasi ekstrak, yaitu kontrol, 5\%, 10\%, $15 \%$, 20\%, masing - masing perlakuan diulang lima kali. Pengamatan dilakukan selama 15 minggu. Hasil penelitian menunjukkan persentase perkecambahan, tinggi tanaman memberikan pengaruh yang nyata, sedangkan jumlah daun, panjang akar, dan berat kering tanaman tidak memberikan pengaruh yang nyata pada pertumbuhan tanaman cabai merah besar.

\section{Kata Kunci : flamboyan, alelopati, cabai merah besar.}

\section{ABSTRACT}

The reach aim to the effect of flamboyant (Delonix regia Hook Raf.) flower extract on the growth of large red pepper plant (Capsicum annuum L.), for use a land under of flamboyant trees. The research design used was Random Block Design, with five treatments extract concentration, control, 5\%,10\%,15\%, and 20\%, each treatment was repeated five time. Observations were made during the 15 weeks. The results showed the percentage of germination and plant height are effect significant, while the number of leaves, root length and dry weight of the plant does not provide effect for the growth of large red pepper plant.

\section{Keywords : flamboyant, allelopathy, large red pepper}

\section{PENDAHULUAN}

Penurunan kualitas lingkungan hidup diperkotaan ditandai dengan semakin meningkatnya pencemaran udara, berdampak pada kesehatan masyarakat. Sumber pencemaran yang paling banyak berasal dari asap kendaraan. Sejak tahun 1950 hingga tahun 2000, hasil emisi dari asap kendaraan meningkat tajam (Sastrawijaya, 2000). Salah satu cara untuk mengatasi pencemaran udara adalah dengan program penghijauan. Tanaman sebagai elemen taman baik berupa pohon, semak ataupun perdu, pada berbagai penelitian memiliki potensi dan peran penting sebagai penyerap polutan udara (Nasrullah, 1997).

Program penghijauan tidak selalu kita lakukan di pinggir jalan, tetapi bisa juga dilakukan di pekarangan rumah. Salah satu tanaman berbunga yang dapat dimanfaatkan untuk program penghijauan di pekarangan rumah adalah pohon flamboyan (Delonix regia Hook Raf). Menurut penelitian Nugrahani et al 2006, pohon flamboyan mampu menyerap gas $\mathrm{No}_{2}$ dengan tingkat serapan tinggi. Salah satu tanaman perdu yang dapat digunakan untuk pekarangan rumah adalah tanaman cabai merah besar (Capsicum annuum L.).

Cabai merah besar merupakan salah satu tanaman sayuran penting di Indonesia, karena mampu memenuhi kebutuhan masyarakat akan rasa pedas pada makanan. Cabai merah juga memberikan warna dan rasa yang dapat membangkitkan selera makan, banyak mengandung vitamin, digunakan sebagai obat-obatan, bahan campuran makanan dan peternakan (Setiadi, 2005). Pohon flamboyan mengandung senyawa alelopati, pada bagian kulit batang mengandung: $\beta$-sitosterol, flavonoid, saponin, carotin, dan alkaloid. Bagian bunga mengandung: tannin, flavonoid, saponin, steroid, alkaloid, dan $\beta$-sitosterol (Jungalwala, 1962).
Penelitian Suardani (1996), ekstrak daun tanaman perindang seperti: akasia, bungur, flamboyan, angsana dan asam keranji mengandung senyawa alelopati yang dapat menurunkan persentase perkecambahan biji kedelai dan jagung sebesar 20\% dan 25\%. Salah satu usaha dalam mengoptimalkan penggunaan lahan untuk meningkatkan nilai tambah yaitu dengan pemanfaatan lahan di bawah naungan pohon flamboyan. Namun karena sifat alelopati flamboyan, perlu diteliti respon tanaman cabai merah besar terhadap pelepasan alelopati bunga flamboyan.

\section{BAHAN DAN METODE}

\section{Waktu dan Tempat Penelitian}

Penelitian dilakukan di Laboratorium Fisiologi Tumbuhan dan Shade House, Jurusan Biologi, Fakultas Matematika dan Ilmu Pengetahuan Alam, Universitas Udayana. Penelitian dilaksanakan bulan Febuari 2014 sampai dengan Mei 2014.

\section{Bahan dan Alat Penelitian}

Bahan - bahan yang digunakan antara lain bunga flamboyan yang telah gugur, benih cabai merah besar, aquades, tanah sebagai media tanam, kapas sebagai media perkecambahan, ekstrak bunga flamboyan. Peralatan yang digunakan adalah cawan petri, timbangan, botol kaca, gelas ukur, polybag berdiameter $15 \mathrm{~cm}$, kain penyaring, penggaris, label, dan blender.

\section{Rancangan Percobaan}

Rancangan yang digunakan Rancangan Acak Kelompok (RAK) dengan lima perlakuan konsentrasi ekstrak, masing - masing perlakuan diulang lima kali. 


\section{Cara Kerja}

Pembuatan ekstrak bunga flamboyan

Bunga flamboyan yang telah gugur diekstrak dengan menggunakan metode maserasi, dengan cara bunga flamboyan yang telah dikumpulkan dicuci bersih, kemudian dikeringanginkan selama 4 hari. Setelah kering diblender halus sehingga menjadi bubuk. Kemudian ditimbang seberat $5 \mathrm{~g}, 10 \mathrm{~g}, 15 \mathrm{~g}$, dan $20 \mathrm{~g}$. Lalu masing - masing dicampur dengan aquades sampai menjadi $100 \mathrm{ml}$ sehingga didapatkan lima konsentrasi yang berbeda yaitu kontrol, konsentrasi $5 \%$, konsentrasi $10 \%$, konsentrasi $15 \%$, konsentrasi $20 \%$. Ekstrak disimpan dalam botol tertutup selama 48 jam sebelum digunakan. Setelah itu ekstrak disaring menggunakan kain penyaring.

\section{Media Perkecambahan}

Cawan petri pada permukaan dilapisi dengan kapas. Di atas permukaan kapas diletakkan masing - masing 30 benih tanaman.

\section{Penanaman Biji}

Setiap cawan petri diberikan perlakuan berupa ekstrak bunga flamboyan sampai media menjadi lembab. Pemberian ekstrak dilakukan setiap pagi hari sebanyak $20 \mathrm{ml}$ ekstrak per sampel. Kelembaban media perkecambahan terus dipertahankan sampai munculnya calon daun.

\section{Pembuatan Media Tanam}

Media tanam adalah polybag hitam berdiameter $15 \mathrm{~cm}$ yang di dalamnya diberi tanah sebanyak 500 gram.

\section{Penanaman Bibit}

Bibit tanaman yang masih berupa benih ditanam selama 7 hari di dalam polybag masing - masing 5 tanaman, diulang sebanyak lima kali. Setelah 7 hari, setiap polybag diberikan perlakuan berupa penyiraman dari ekstrak bunga flamboyan setiap hari sekali sebanyak $20 \mathrm{ml}$. Setiap minggu tanaman dibersihkan dari tanaman penganggu.

\section{Analisis Data}

Data persentase perkecambahan, tinggi tanaman, jumlah daun, panjang akar, dan berat kering dianalisis secara statistik dengan uji ANOVA (Analysis of Variance) taraf 5\% $(\mathrm{p} \leq 0,05)$. Jika menunjukkan perbedaan yang nyata, maka dilanjutkan dengan uji perbandingan berganda yaitu uji Duncan menggunakan software SPSS Release for Window versi 17.

\section{HASIL DAN PEMBAHASAN HASIL}

Persentase perkecambahan tanaman cabai merah besar menunjukkan penurunan pada konsentrasi $10 \%$, kemudian naik pada konsentrasi $15 \%$ dan $20 \%$ (gambar 1). Konsentrasi ekstrak bunga flamboyan berpengaruh nyata terhadap persentase perkecambahan cabai merah besar. Persentase perkecambahan tertinggi terdapat pada $0 \%$ dengan persentase perkecambahn $81,8 \%$, dan terendah pada $10 \%$ dengan persentase perkecambahan $41,2 \%$.

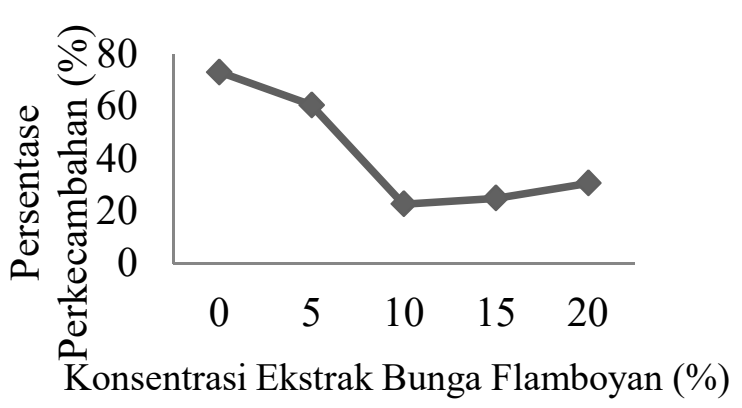

Gambar 1. Grafik persentase perkecambahan cabai merah besar

Tinggi tanaman cabai mengalami peningkatan setiap minggunya. Konsentrasi ekstrak bunga flamboyan berpengaruh nyata terhadap tinggi tanaman. Pada pengamatan minggu terakhir tinggi tanaman tertinggi terdapat pada kontrol dengan tinggi $29 \mathrm{~cm}$, dan terendah pada konsentrasi 15\% dengan tinggi 20,2 cm (gambar 2).

Jumlah daun cabai merah besar, mengalami peningkatan setiap minggunya. Pada minggu ke - 15 konsentrasi ekstrak 5\%, 15\%, dan 20\% mengalami pertambahan jumlah daun yang lebih tinggi dibandingkan dengan kontrol dan konsentrasi $10 \%$. Konsentrasi ekstrak bunga flamboyan tidak berpengaruh nyata terhadap jumlah daun. Semua konsentrasi tidak ada perbedaan yang nyata. Pada minggu ke - 15 jumlah daun tertinggi terdapat pada konsentrasi 5\% dengan jumlah daun 17 helai, dan terendah terdapat pada konsentrasi 20\% dengan 12 helai (gambar 3).

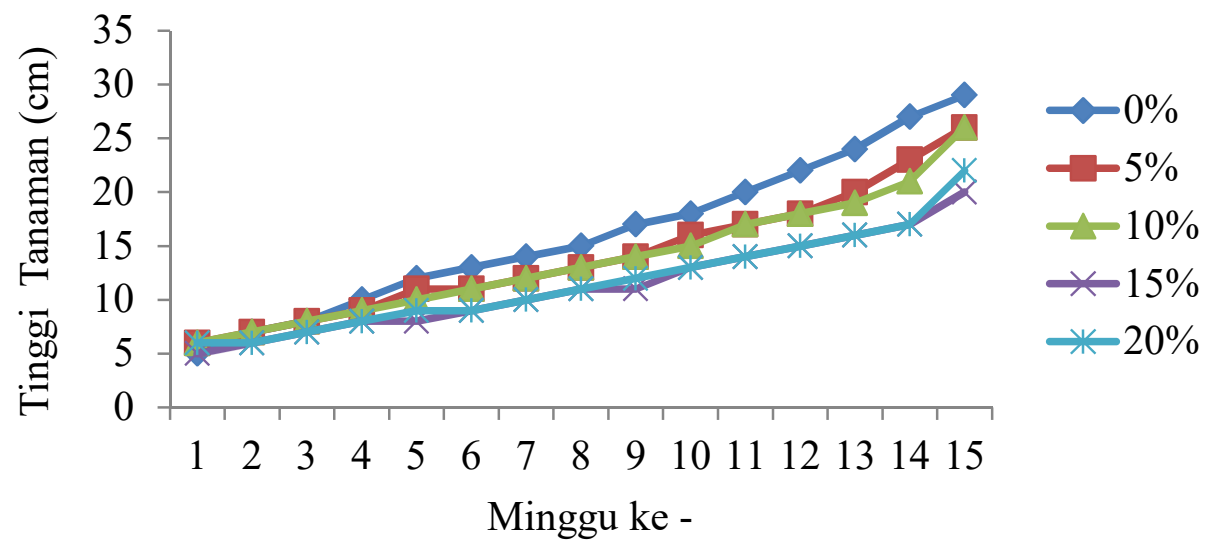

Gambar 2. Grafik tinggi tanaman cabai merah besar minggu 1-15 


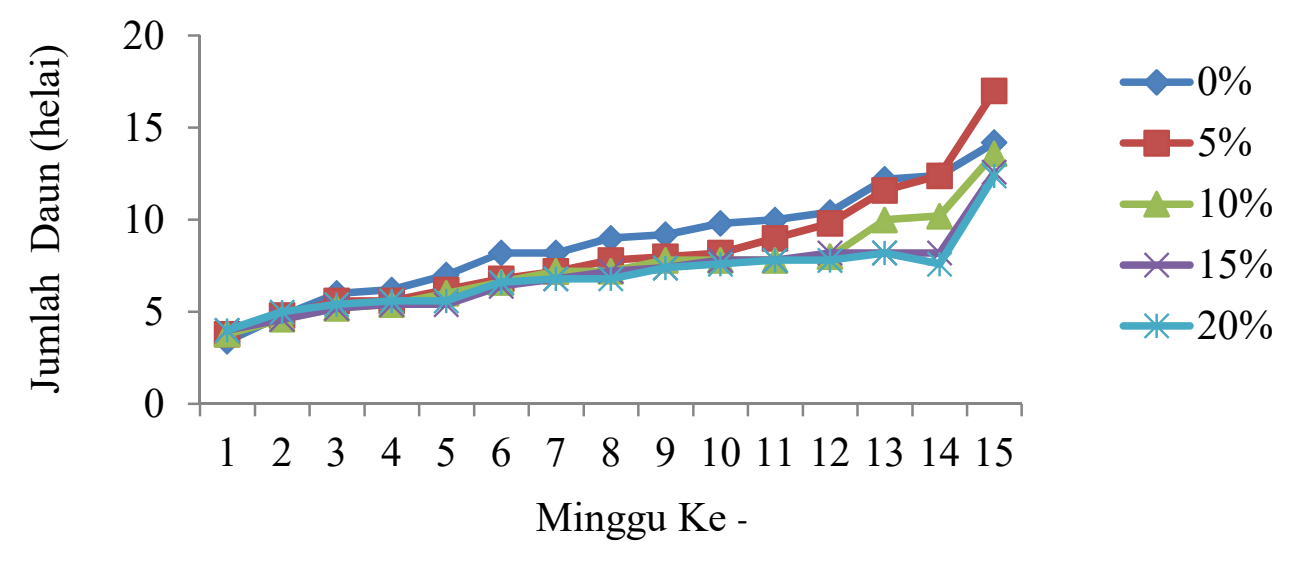

Gambar 3. Grafik pertambahan jumlah daun tanaman cabai merah besar

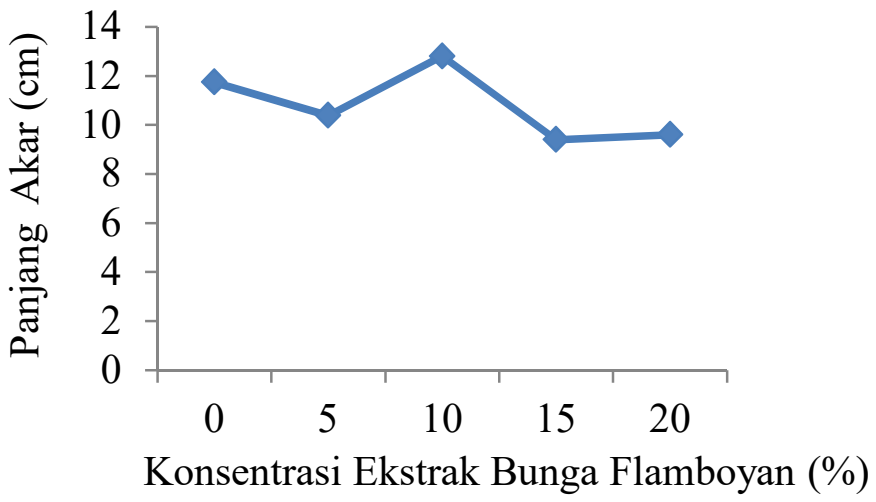

Gambar 4. Grafik panjang akar cabai merah besar.

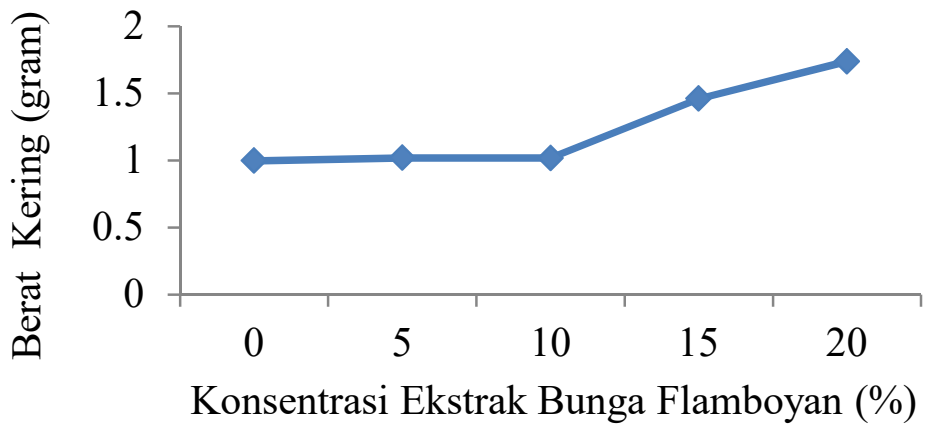

Gambar 5. Grafik berat kering cabai merah besar

Konsentrasi ekstrak bunga flamboyan tidak berpengaruh nyata pada panjang akar cabai merah besar. Panjang akar tanaman pada semua konsentrasi tidak ada perbedaan yang nyata. Panjang akar tertinggi terdapat pada konsentrasi $10 \%$ dengan panjang akar $12,8 \mathrm{~cm}$ dan terendah pada konsentrasi $15 \%$ dengan panjang akar 9,46 cm (gambar $4)$.

Berat kering tanaman cabai merah besar menunjukkan penurunan pada kontrol dan semakin tinggi konsentrasi, berat kering tinggi tanaman semakin meningkat. Berat kering tertinggi terdapat pada konsentrasi $20 \%$, dan terendah pada kontrol. Hasil ANOVA menunjukkan konsentrasi ekstrak bunga flamboyan tidak berpengaruh nyata terhadap berat kering. Berat kering tanaman cabai merah besar tidak ada perbedaan yang nyata.

\section{PEMBAHASAN}

Pemberian ekstrak bunga flamboyan dengan tingkat konsentrasi yang berbeda memberikan pengaruh pada persentase perkecambahan cabai merah besar. Persentase perkecambahan tertinggi terdapat pada kontrol. Senyawa tannin didalam ekstrak bunga flamboyan menghambat aktivitas enzim - enzim yang melakukan degradasi cadangan makanan dalam benih sehingga energi untuk tumbuh yang dihasilkan sangat rendah dan dalam waktu yang lebih lama menurunkan potensi perkecambahan (Kristanto, 2003). Persentase perkecambahan terendah pada konsentrasi $10 \%$. Faktor lainnya adalah aktivitas hormon, aktivitas hormon Auksin, Giberelin, dan Sitokinin dapat menekan daya hambat senyawa alelopati dari ekstrak bunga flamboyan (Sutopo. 1984).

Pemberian ekstrak bunga flamboyan dengan konsentrasi yang berbeda memberikan pengaruh yang nyata pada tinggi tanaman. Pada semua konsentrasi ada perbedaan yang nyata. Tinggi tanaman cabai merah besar mengalami peningkatan setiap minggunya, dimana pada minggu terakhir tinggi tanaman tertinggi terdapat pada kontrol dan terendah pada konsentrasi $15 \%$. Tinggi tanaman dipengaruhi banyak faktor internal dan ekternal, diantaranya ketersediaan unsur hara, $\mathrm{pH}$ tanah, suhu, cahaya, angin, umur tanaman, aktivitas 
enzim, aktivitas hormon auksin, giberelin, sitokinin, dan hambatan dari luar berupa senyawa alelopati (Einhellig, 1995). Hambatan pertumbuhan tinggi tanaman cabai merah besar terjadi karena senyawa tannin didalam bunga flamboyan. Proses tersebut diawali di membran plasma, kemudian terjadi kekacauan struktur, modifikasi saluran membran, atau hilangnya fungsi enzim ATP-ase, sehingga berpengaruh terhadap penyerapan dan konsentrasi ion dan air yang kemudian pembukaan stomata dan proses fotosintesis (Rijal, 2009).

Jumlah daun tanaman cabai merah besar juga mengalami peningkatan setiap minggunya. Pemberian ekstrak bunga flamboyan tidak berpengaruh nyata pada jumlah daun tanaman cabai merah besar. Tidak ada perbedaan yang nyata pada semua konsentrasi ekstrak. Pada minggu terakhir jumlah daun cabai tertinggi pada konsentrasi $5 \%$, dan terendah pada konsentrasi $20 \%$. Hal ini mungkin terjadi karena senyawa tannin yang seharusnya menghambat jumlah daun tanaman, justru memacu pertumbuhan pada konsentrasi yang tepat (optimal) dan dapat menghambat pada konsentrasi yang lebih tinggi. Keefektifan zat tumbuh eksogen hanya terjadi pada konsentrasi tertentu, sedangkan pada konsentrasi yang terlalu rendah tidak efektif (Danoesastro,1964 ). Dan adanya kemungkinan kandungan hormon IAA pada ekstrak bunga flamboyan.. Terjadinya penghambatan jumlah daun pada konsentrasi 20\% disebabkan flavonoid mengaktifkan enzim IAA oksidase yang menguraikan IAA sehingga pemanjangan sel menjadi terhambat (Rice, 1984).

Pemberian ektrak bunga flamboyan tidak berpengaruh nyata terhadap panjang akar cabai merah besar. Pada semua konsentrasi ekstrak tidak ada perbedaan yang nyata. Panjang akar tertinggi terdapat pada konsentrasi $10 \%$ dan terendah pada konsentrasi $15 \%$. Hal ini sesuai dengan pernyataan Rice (1984) bahwa senyawa fenol yang terkandung didalam bunga flamboyan memacu pertumbuhan hipokotil dan radikula pada kadar yang rendah, namun menghambat pada kadar yang tinggi. Disisi lain senyawa alelopati yang mampu menekan pertumbuhan tertentu seringkali tidak berdampak diaplikasikan pada tumbuhan lainnya (Putnam, 1997). Panjang akar adalah perpanjangan sel - sel di belakang meristem ujung, dimana panjang akar dipengaruhi oleh banyak faktor diatas tanah antara lain transport karbohidrat ke akar yang dapat mempengaruhi pertumbuhan akar, temperatur, kelemababan tanah, porositas tanah, agen biologis, bahan beracun, dan tersedianya air dan mineral didalam tanah (Gardner et al, 1991).

Pemberian ekstrak bunga flamboyan juga tidak berpengaruh nyata terhadap berat kering tanaman cabai merah besar. Pada semua konsentrasi ekstrak tidak ada perbedaan yang nyata. Berat kering cabai merah besar tertinggi pada konsentrasi $20 \%$, dan terendah pada kontrol. Senyawa tannin yang terkandung didalam bunga flamboyan tidak memberikan pengaruh pada berat kering tanaman, dimana berat kering tertinggi terdapat konsentrasi paling tinggi. Hal ini mungkin bisa disebabkan konsentrasi ekstrak bunga flamboyan masih rendah, belum termasuk konsentrasi optimal, sehingga bisa memacu pertumbuhan, karena tanin yang terkandung dalam bunga flamboyan yang seharusnya menghambat pertumbuhan tanaman, justru merangsang pertumbuhan tanaman. ). Menurut Steinsik et al (1982) dan Shettel dan Balke (1983) pertumbuhan dan perkembangan tanaman tergantung pada konsentrasi ekstrak, sumber ekstrak, temperatur ruangan, dan jenis tumbuhan yang dievaluasi serta saat aplikasi tanaman.

\section{KESIMPULAN}

Pemberian ekstrak bunga flamboyan berpengaruh nyata terhadap persentase perkecambahan, tinggi tanaman, tetapi tidak berpengaruh nyata terhadap jumlah daun, panjang akar, dan berat kering. Tanaman cabai merah besar salah satu tanaman yang bisa dimanfaatkan di bawah naungan pohon flamboyan.

\section{KEPUSTAKAAN}

Danoesastro, H. 1964. Zat Pengatur Tumbuh Dalam Pertanian. Yayasan Pembina Fakultas Pertanian Universitas Gadjah Mada. Yogyakarta

Einhellig, F. A. 1995. Mechanism of action ofallelochemicals in allelopathy. In: Inderjit, K.M.M. Dakhsini., F. A. Einhellig Eds. Allelopathy,Organism, Processes and Applications. American Chemical Society. Washington DC. 96-116.

Gardner, F.P., B.R. Pearce dan R.L. Mitchell. 1991. Fisiologi Tanaman Budidaya. Universitas Indonesia. Jakarta.

Jungalwala, F. B., Chama H. R. 1962. Carotenoidsin Delonix regia (Gulmohor) Flower. Dept Of Biochem, IIS Bangalore. Biochem. J 1962; 85-93.

Kristanto, B. A., B. Sukarnto., Nuraini dan E. Y. Suyanti 2003. Alelopati Alang - Alang (Imperata cyclindrical L. Beauv) dan teki (Cyperus rotundus L.) Pada Perkecambahan dan Pertumbuhan Berbagai Tanaman Graminase dan Legum. Jurnal Pastura 7 (2) : 48 - 54.

Nasrullah, N. 1997. Kemampuan Tanaman Jalan Raya Dalam Menyerap Polusi Udara $\left(\mathrm{NO}_{2}\right)$. Laporan riset unggulan terpadu III, Bidang teknologi perlindungan lingkungan tahun 1995-1997. IPB. Bogor.

Nugrahani, Pangesti., N. Nasrullah., E. L. Sisworo. 2006. Faktor Fisiologi Tanaman Tepi Jalan Yang Menentukan Kemampuan Serapan Polusi Udara Gas Noz. Risalah Seminar Ilmiah Aplikasi Isotop dan Radiasi 2006. Hal 75 -80 .

Putnam, A. R. 1997. Allelopathy : Can it be managed to benefit horticulture?. Hort. Sci 21(3):411-413.

Rice, E. L 1984. Allelopathy (2nd). Academic Press. New York.

Rijal, N. 2009. Mekanisme Dan Penerapan Serta Peranan Alelopati Dalam Bidang Pertanian. Jurnal Penelitian. Universitas Muhammadiyah Malang. Malang.

Sastrawijaya, A. T. 2000. Pencemaran Lingkungan. Rineka Cipta. Jakarta.

Setiadi, 2005. Bertanam Cabai. Penebit Swadaya. Jakarta.

Shettel, N. L. and N. E. Balke. 1983. Plant growth response to several allelopathic chemicals. Weed Sci. 31:293-298.

Steinsiek, J. W., L. R. Oliver and F. C. Collins. 1982. Allelopathic potential of wheat (Triticum aesativum). Weed Sci. 30:495-497.

Suardani. 1996. Pengaruh Ekstrak Daun Dari Tanaman Perindang Terhadap Perkecambahan Biji Jagung Dan Kedele. Jurusan Biologi Fakultas Matematika dan Ilmu Pengetahuan AlamUniversitas Udayana. Denpasar. Skripsi. Tidak Dipublikasikan.

Sutopo, Lita. 1984. Teknologi Biji. Rajawali Press. Jakarta. 